and liberate the wheel ; the $\operatorname{cog} \mathrm{T}_{1}$ will then immediately operate upon the hook $\mathrm{F}_{1}$ and lift the other pallet. Meanwhile the pendulum swings away to the right, carrying the pallet $\mathrm{P}_{2} \mathrm{P}_{2}$, and returns with it, but as there is now no $\operatorname{cog} p_{2}$ to receive it, it falls to the lower position corresponding to that now occupied by $P_{1} P_{1}$, the excess of its fall over its rise, upon the pendulum as in the preceding case constituting the impulse.

This form of gravity escapement has been further modified and improved for ordinary use by Sir Edmund Beckett. ${ }^{1}$ The only way in which variations in the force of the clock-train can disturb the pendulum in these escapements is by putting more or less pressure upon the locking studs, giving the pendulum more or less trouble in liberating the escapement; and with reference to this you must not be deceived by so-called improvements for detaching the pendulum completely from the escapement, for they really never do so, and generally by the number of pieces employed, hamper the pendulum with much more friction than that to which it would be exposed by direct communication with the clock-train.

You will see that the general effect of a gravity escapement is to make the pendulum move rather faster than if it were a free one, because the weight of the pallets is equivalent to two smaller pendulums attached to it during the greater portion of its swing. And the effect of any increase of pressure is quite the reverse of what would happen with a direct escapement, for it increases the pressure upon the lockings without increasing the impulse, and will consequently cause the arc of vibration to fall off.

The last clock-escapement I shall describe is a detached one (see Fig. 18), the design of the Astronomer Royal, Sir George Airy.

There is only one pallet, A, the other arm, B, being merely a safety-catch and counterpoise. That tooth of the escape-wheel, $c$, is not really resting upon the dead face of the pallet, though it is very close to it, the wheel being at present held by the detent, $D$, fastened to the clock frame.

The pendulum is supposed to have reached the limit of its excursion towards the left, and to be now returning. When it reaches a certain angle before zero, a pin, $H$, in the arm $K$ (which swings with the pendulum and pallets), passes under the detent, lifts it, and unlocks the wheel at just that instant that the tooth $\mathrm{C}$ shall fall immediately upon the impulse face of the pallet without touching the dead face at all. The tooth slides down the impulse face, giving impulse to the pendulum; meanwhile, the pin $\mathrm{H}$ passes on and allows the detent to fall in time to catch the succeeding tooth L. The tooth quits the impulse face when the pendulum is at the same angle after zero that it was at before zero when the impulse began. Thus you get an equal impulse when the pendulum is falling as when it is rising, the advantage of which I pointed out to you when we were discussing Graham's dead escapement. Besides this, you get no dead friction, and the pendulum is almost completely detached from the clock-train. Upon return. ing the pin $H$ clears the detent this way. You see that long spring beneath the detent, commencing near its middle, and projecting beyond its extremity upon the right ; just now, in unlocking, the extremity of the detent supported this spring, and detent and all gave way before the pin $H$. But upon returning, the extremity of the detent of course gives no support to the spring, and the pin $H$ pushes it upon one side without disturbing the detent. This escapement is used in the normal sidereal clock at Greenwich.

(To be continued.)

I The Wesiminster Clock has one of his forms. A locking stud is placed upon the back of one pallet and the front of the cther, anc1 there are two collections of arms (of three cach) on either siric of the cog-wheel, to mee them. The $\operatorname{cog}$-wheel itself has also three cogs. This escape wheel, with a sconds pendulum, turns once in sux seconds, and its velucity is controlled by a tly.

\section{CHARLES SAINTE-CLAIRE DEVILLE}

M CHARLES SAINTE.CLAIRE DEVILLE, the 1. distinguished geologist and meteorologist, and brother of M. Henri Sainte-Claire Deville, the well-hnown chemist, was born of French parents in 1814 , at $S t$. Thomas, in the West Indies. At the age of ig he was enrolled a pupil of the School of Mines, in Paris, and after a course of study there undertook, at hisown expense, a scientific expedition extending from 1839 to 1843 , to the Antilles, Teneriffe, and Cape Verd Islands. He spent upwards of a year investigating the geology of Guadaloupe, and wrote a detailed account of the terrible earthquake which laid waste that island in 1843 . The results of this expedition he published in two series of memoirs, the one appearing from 1856 to 1864 , on the geology of the Antilles, Tenerife, and Cape Verd Islands, and the other from I861 to 1864 , principally on the meteorology of the Antilles. He was sent by the Institute to Italy in 1855 to examine the great eruption of Vesuvius which occurred in that year. After attentively following and investigating the eruption through all its phases, he wrote a description of it in a series of letters addressed to M. Elie de Beaumont, which were published in the Comptes Rendus and the Moniteur during i 856 . He also, in 1858 , published an interesting account of the volcanic eruptions of Stromboli, in the Lipari Isles, and in later years, various papers on other volcanic eruptions. Several memoirs on different points in chemistry and physics were written by him about 1852 , and for several years he filled with distinction the chair of geology in the College of France, formerly held by the illustrious Élie de, Beaumont. On December 28,1857 , he was elected a member of the French Academy of Sciences in the place of Dufrenoy, and on August I3, I862, was made an officer of the Legion of Honour.

During the time he worked in the laboratory of his friend M. Dumas, he discovered the amorphous and insoluble form of sulphur, thus pointing out for the first time the fact that an elementary body may at will be made to assume two totally distinct states, differing from each other not only as regards their physical characters, but also as regards their essential chemical properties. This discovery was published in 1852 .

Shortly after this his attention began to be more decidedly attracted towards meteorology; so much so, indeed, that for the past twelve years he appears in his writings almost exclusively as a meteorologist. Indeed the meteorological work, both scientific and administrative, which he undertook to do, and which he did, was so laborious and harassing as to leave him little time for other pursuits. By this work, however, he has left his mark unmistakably on the meteorology of France.

The fruits of his meteorological researches were given to the world in a remarkable series of papers in the Comptes Rendus during $1865-67$, on the "Periodic Variations of Temperature." The object of this investigation was to prove the existence of annual and super-annual periodic perturbations of temperature, and to state with precision the character and nature of these periods. Having shown the occurrence of similar perturbations of ternperature on four days of the same date in February, May, August, and November, these days being placed on the terrestrial orbit at equal intervals, and which, by the way, correspond with the dates of the festivals of the "Ice Saints," he inquired how far similar perturbations occur on any four days of the year separated from each other by equal intervals of time. Since the observations showed that some years and groups of years presented for the same days perturbations different from those of other years, being sometimes above and sometimes below the normal means of the days, an inquiry was raised as to the limits of the antagonism thus disclosed both as regards the amount and the cycle of years it embraced. Lastly, since these perturbations, if they exist, must exercise an important influence on all the 
other atmospheric conditions, the still larger inquiry was suggested, viz., the sifting and separation of the facts so as to make them disclose the nature and limits of this influence in each particular class of meteorological pheno. mena. The theory advanced to account for these perturbations was that first suggested by Erman of Berlin, by which they are considered as due to different streams of meteoric matter which are periodically interposed between the earth and the sun-a theory which in view of the facts is open to serious doubt. But the great value of these memoirs lies in their suggestiveness and in the important lines of meteorological inquiry therein pursued and indicated. Indeed the author states that a main object he had in view would be gained if he thereby enlisted the younger meteorologists to aid in establishing clearly in meteorology the notion of periodicity, which in truth is only another name for law and harmony, the evolution of which from facts apparently so entangled and so discordant is the problem presented by meteorology. It may be added here that his two daughters materially assisted him in the laborious calculations for this work. He subsequently wrote various papers on the connection between atmospheric pressure and temperature, on the aurora, and on terrestrial magnetism.

He was one of the founders of the French Meteorological Society, and it was during his term of presidency of the Society that the Meteorological Observatory of Montsouris was established chiefly through his infiuence and that of $M$. Dumas, for the special purpose of investigating terrestrial physics, inclusive of the work usually undertaken by meteorological observatories. This observatory remained under his direction from the date of its establishment in June, I 869, to June, I 872 , when he was appointed Inspector.General of Metearological Stations in France. Under his management and that of his successor, Marié Davy, the well-known meteorologist, the Montsouris Observatory has gradually come to occupy, as our readers are doubtless aware, a well-marked sphere of action which we hope similar observatories in other countries will not be slow to adopt. This special sphere of action concerns the application of meteorology to the great national questions of agriculture and public health, particularly the health of large towns; and it consists in a welldevised scheme of chemical and microscopical observations regularly conducted, having for their object the investigation of the composition of the air, more especially as regards the variations of its aqueous vapour, carbonic acid, nitric acid, and ammonia, and its organic and inorganic impurities.

As Inspector-General of the French meteorological stations, he went to Algiers for the purpose of organising the meteorological stations of that country. Owing to the fatigue incident to this journey and the inclement weather he experienced his health was impaired, and it remained in a weak state up to the last. This illness was the more severely felt by a system already enfeebled by a malady which he had contracted thirtythree years before in the service of science. When in 1843 he had just completed bis three years' exploration of the volcanic isles of Africa and the Antilles, and it only remained to him to put into shape the rich materials he had collected, the great earthquake, already alluded to, of Pointe-à-Pitre, Guadaloupe, occurred, by which he not only lost the whole of his valuable collections, but was called to mourn the loss of his uncle and several other members of his family, who perished in that catastrophe. The mental suffering and fatigue consequent on these òisasters brought on a rheumatic affection, from which he never recovered, and it was to an aggravated form of this malady that he succumbed on October Io, at Paris.

Thus died Charles Sainte-Claire Deville in the midst of his work-a man of singular modesty and amiability of disposition, as well as an enthusiastic worker in science. His funeral was largely attended, but in accord ance with a desire expressed in his will, no official deputation of the Academy was present on the occasion, and no funeral oration was pronounced over his grave.

\section{RECENT CAVERN RESEARCHES IN NEW ZEALAND}

THE following is the substance of a paper on Cave-Hunting, by Dr. Haast, read at the Philosophical Institute of Canterbury, New Zealand, some time since, and which ;has been recently forwarded to us.

In the spring of the year $1872, \mathrm{Mr}$. E. Jollie having suggested to Dr. J. Elaast, president of the Institute of Canterbury, that an inspection of the Moa-bone Point Cave, and of the ground near its entrance, would probably help to fix the period of the extinction of the Moas, a subscription list was at once opened, and the results enabled Dr. Haast to commence the work and to carry it on for seven weeks.

Moa-bone Point Cave is sittrate on the eastern side of the Middle Island, in Banks Peninsula, an extinct volcanic system of large dimensions, which is believed to have been an island in Post-pliocene times, and to have been subsequently raised about 20 feet. The cavern seems to have been a pre-existing hollow in a doleritic lava stream, enlarged by the waves during the insular period. It was well known to Europeans at the very beginning of the Canterbury Settlement, was even inhabited by some of the earliest settlers, of whom ample traces were left behind. Immediately east of the cavern is a small plain, occupied with dunes of drift sand, and bounded seaward by a line of boulders, detached from a small doleritic headland on the western side of the cave when the peninsula was an island.

The entrance to the cavern is from 13 to 14 feet above high water, 30 feet broad and 8 feet high, but is partially occupied by a mass of rock 12 feet long, 6 feet broad, and 10 feet high. This cpens into the "First Chamber," which measures, from north to south, IO2 feet long, 72 feet broad towards the middle, and about 24 feet high. From its inner or southern end a small passage leads into a "Second Chamber," I 8 feet long in a direction N. by W. to S. by E., I4 feet wide, and I I feet high. At the inner end of this is a passage, 3 feet high, and 2.5 feet broad, leading into a "Third Chamber," measuring 22 feet from $N$. to S., about 20 feet high, and averaging 16 feet in width.

The floor of the first chamber consisted generally of remains betokening European occupation, but everywhere below them were portions of shells of edible molluscs. These beds gradually thinned out southwards, till at the entrance of the second chamber there was a continuous floor of marine sand.

The explorations appear to have been almost exclusively confined to the first chamber, and to have been commenced by digging two trenches, crossing each other at right angles, near the centre of the chamber. Several other excavations were made, and in one of them, towards the western side of the chamber, the following was the succession of beds, in descending order :-

ft. in.

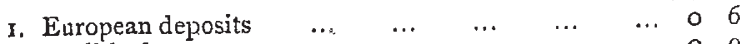

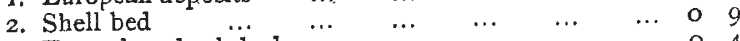

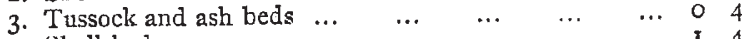

$\begin{array}{lllllllll}4 . & \text { Shell beds } & \ldots & \ldots & \ldots & \ldots & \ldots & \ldots & \text { I }\end{array}$

5 . Ash beds $\ldots$.. $\ldots$ w $\begin{array}{llllll}\ldots & \ldots & \ldots & \ldots & 0 & 2\end{array}$

6. Ash beds, mixed greatly with shells $\ldots, \ldots, \ldots$ o ro

$\begin{array}{llllllll}\text { 7. Ash and dirt beds } & \ldots & \ldots & \ldots & \ldots & \ldots & \circ & 2 \\ 8 & \end{array}$

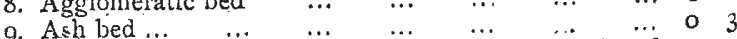

9. Ash bed ... 1 . Marine sands (excavated to a depth of $\dddot{\gamma} \mathrm{ft}$, and found by boring to extend $5 \mathrm{ft}$. deeper before reaching the rock at the bottom of the cavern) $\ldots \quad \ldots \quad \ldots \quad \ldots 12 \quad 0$

Whilst the beds, as might have been anticipated from their characters, were neither equally numerous nor equally thick in different sections, the following important features presented themselves every where :-

The basal bed was uniformly the "marine sand" (No. 10); the asli and shell bed (No. 6), the ash and dirt bed (No. 7), and the irgolomeratic bed (No. 8), were also well-defined horizons; the shells found in the sixth bed and those above it belonged to species still occupying the adjacent estuary, and the same forms were found in all the beds alike; there were no shells in the 